\title{
Belgian Botany: a Record of War Time.
}

THE Botanical Institute, close to the Botanic i of the vegetation of the region since the salt-water Gardens in Brussels, which bears the name invasion finally ceased at the close of the war (Figs. of that distinguished Belgian botanist, Léo Errera, I and 2).

has resumed its activities since the war and is again under the guidance of Prof. Jean Massart of the University of Brussels. A large volume, Part 2 of vol. Io of the collected papers of the Institute, has recently appeared, published in Brussels, with many plates, text-figures, charts, and maps, together with a list of the communications published in the earlier volumes. Most of the papers have previously appeared in scientific journals in France or Belgium, but we note as apparently new contributions a brief note by Henri Micheels, comparing the effect upon seedling germination of the anions $\mathrm{Cl}$ and $\mathrm{NO}_{3}$ and the cations $\mathrm{K}$ and $\mathrm{Na}$, a note reporting the presence of calcium thiosulphate in Achromatium oxaliferum Schew by Germaine Hannevart, and a continuation of phenological observations by E. Vanderlinden, meteorologist to the Belgian Royal Meteorological Institute, which is lavishly illustrated by charts, and a description of the vegetation succeeding upon the war-time inundations of the Yser and upon the ruins of Nieuport.

Prof. Massart's earlier studies of the vegetation of the Belgian littoral make him the natural chronicler of the intense subsidiary struggle waged among the vegetation of this region and maintained long after the armistice of I9I8. Behind the dunes bordering the Belgian coast there lies a long stretch of country, the level of which is intermediate between the level of the high and low tides of the sea. On October 29, I9I4, the Belgian engineers opened the locks at high tide and allowed the sea to flow over this portion of their front, thus preventing the farther advance of the German forces, and giving their own heroic troops a well-earned respite. For four long years these inundations remained upon the land, fully maintained in winter by the natural rainfall and humid atmosphere, in the drier season assisted by the regulated

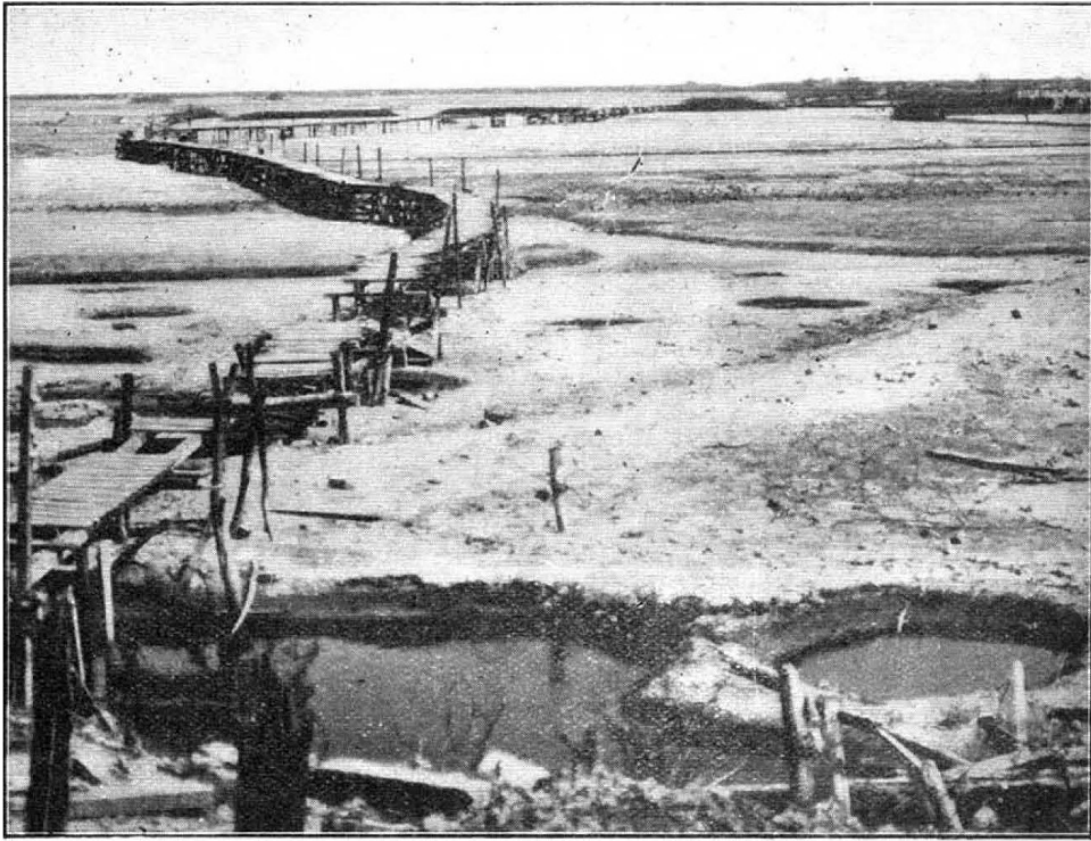

Fig. r.-Raised footpath near Ramscapelle after retreat of floods, May rgrg. Only vegetation, tufts of Phragmites communis in distance.

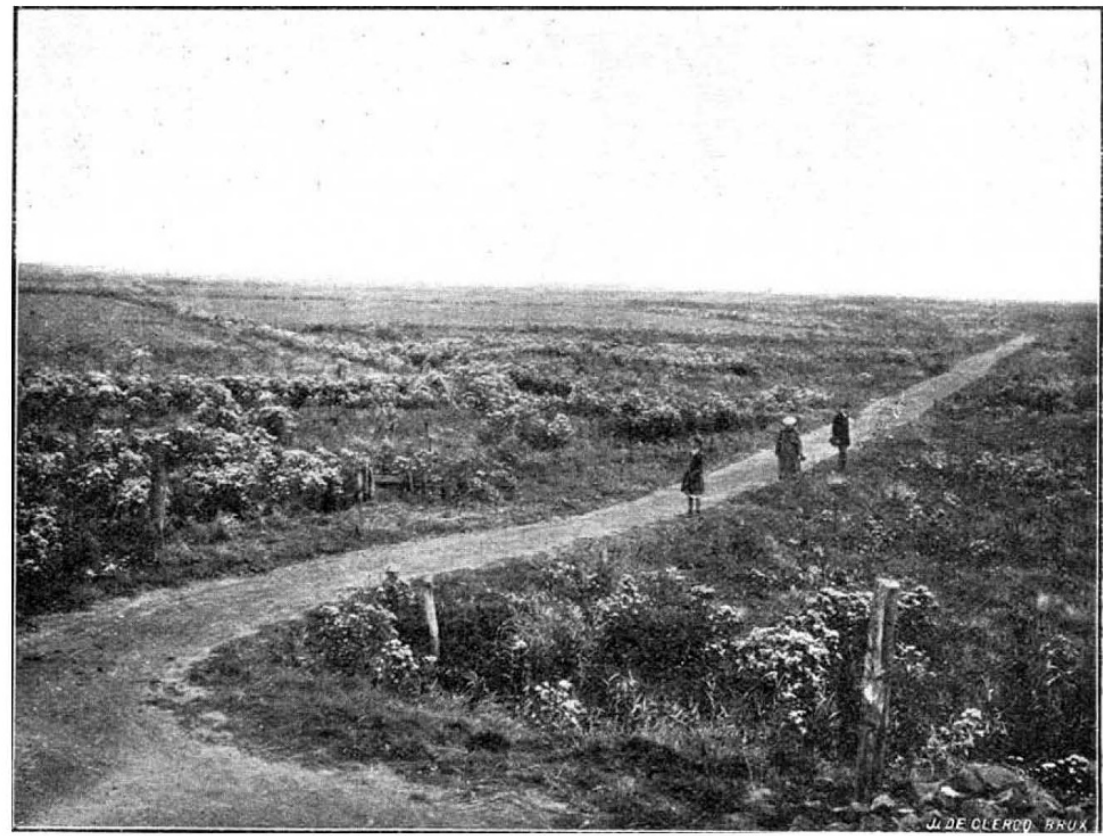

FIG. 2.--Same path in September I9zo. Some of supports of original planking left, ground covered with Aster tripolium in flower, especially around shell holes on foreground on right. influx of the sea controlled by the Belgian engineer service. Prof. Massart, aided by official photographs and maps, gives a vivid account of the effect of these conditions upon the vegetation, and, by further striking photographs of his own, records the rapid recovery the sea, rapidly succumbed before the salt waterwillows, poplars, elms, etc., all dying as the salt tide reached their roots. At Blankaert, where the waters of the Yser diluted the salt water, Massart figures 
an interesting group of willows which, inundated for more than a metre above their normal root level, have developed a fresh crop of roots at the new water level, increasing the girth of their trunks above this new fringe of roots.

Very few plants replaced the displaced vegetation, and when the water retreated the mud was left bare and desolate. Massart describes the red alga, Porphyra laciniata, growing in the brackish water of a shell-hole, but no longer red in colour. Fringing the salt inundation were typical halophytes like Aster tripolium, Atriplex littoralis, etc. As the waters receded and the former denizens returned to the attack these plants have to retreat-in I9I9 in the ascendant throughout the region, I920 finds them fighting desperately for a foothold upon the saltincrusted edge of many a shell-hole. Active in the attack upon these war-time invaders is Agropyrum repens, a plant the fighting qualities of which are known to many an allotment holder. Phragmites communis had maintained itself during the inundation upon occasional islets rising above the general flood level, where it dispossessed practically all other inhabitants trying to maintain themselves before the salt flood. As the mud dries, long slender rhizomes descend from these little knolls and Phragmites eagerly advances to recover its old domain. An interesting observation made by Massart is that as the yellowflowered halophyte Aster tripolium, typical of the salt marsh, recedes before the reconquering flora of the fertile Belgian plain of peace, there is a fringe of the form of this aster with purple-ray florets to be found maintaining itself for a time upon the more fertile, less saline soil. This occurrence of the purple form is being made the subject of further study in a biological laboratory installed upon the Yser.

Another result of the war is that some of the earlier scientific communications, republished from French scientific journals, give the observations made by Prof. Massart in his enforced exile during those tragic years, including a most interesting discussion of the striking features of the Riviera vegetation as they appear to a Belgian ecologist. The reprinting of Prof. Massart's polemical contribution to the Revue de Paris of October I918, "Les Intellectuels Allemands et la Recherche de la Vérité," seems inappropriate in a volume of this nature, but the perusal of this article may be recommended to any British botanists who may have so far failed to realise the difficulties that still lie in the way of any genuine international Botanical Congress, of the type that would have been held in London before the present date if the war had not intervened.

\section{Methods and Costs of Coal-mine Haulage. ${ }^{1}$}

\section{By Prof. Henry Lours.}

THE series of bulletins issued under the authority of the University of Illinois has achieved an enviable reputation among mining engineers in this country, and the latest addition fully sustains this reputation. Its origin differs slightly from preceding bulletins, inasmuch as it has been prepared under a co-operative agreement between the Engineering $\mathrm{Ex}$ periment Station of the University of Illinois, the Illinois State Geological Survey, and the United States Bureau of Mines. Incidentally, such a method of work may be recommended to the serious attention of universities in this country; some of them have indeed moved in this direction, but none has gone so far as has the University of Illinois.

The present bulletin could scarcely come at a more opportune moment, seeing that attention in this country is being focussed upon the possibilities of electric locomotive haulage in collieries, and the pamphlet under review contains a full and authoritative exposition of what is being done in one of the most important of the coal-mining regions of the United States, Illinois ranking in coal output next to Pennsylvania, with an annual production exceeding one-third of that of Great Britain. Individual mines, moreover, are verv large, seeing that in some of them, as is here stated, "600o or more tons of coal per day are hoisted in 5-ton capacity cars and that 1200 or more cars per day, or I50 per hour," must be concentrated at the shaft bottom from various parts of the mine; there is nothing on the same scale in this country.

The bulletin is divided into six chapters. The first contains merely a brief introduction and explanation of the scope of the subject. The second chapter deals briefly with the evolution of mine haulage and shows how great has been the change in practice within the last twenty years: "In $1899,87 \cdot \mathrm{I}$ per cent. of the tonnage in Illinois coal-mines was handled by animal

1 Engineering Experiment Station, University of Illinois. Bulletin No. r 32: "A Study of Coal-mine Haulage in Illinois," by H. H. Stoek, T. R. Fleming, A. J. Hoskin. haulage. Locomotives hauled 2.5 per cent., ropes 7.9 per cent., and tramming 2.5 per cent., but in I92 I it appears that both ropes and tramming were practically obsolete and that $9 \mathrm{I} \cdot 2$ per cent. of the coal was moved by locomotives, and only 8.8 per cent. by animals.'

Of the locomotives, by far the greatest number are electric ; considerable attention is now being paid to the track, $45^{-}$to 60 -pound rails being used on the main roads. It appears that the first electric locomotive was tried in a colliery in Illinois so far back as I 888 , but their introduction on any scale only came eleven years later. These locomotives were trolley locomotives and could only run on main roads; gathering from the coal face was still mainly done by mules, but in rgoo the cable locomotive was introduced, consisting of a locomotive furnished with a long flexible conducting cable carried on a reel, which enabled it to run on rails not equipped with trolley wires. For steep dips crab locomotives have been used, consisting of a locomotive with a separate motor driving a drum carrying a steel winding rope, by means of which cars could be hoisted up gradients too steep for the locomotive to travel. Another method of getting over the latter difficulty was the introduction of the rack-rail locomotive, similar to the type used on certain mountain railways.

Storage battery locomotives were introduced about I 899 , and they have gradually been improved until their use is now very general ; they are so built that they are considered quite safe for operation even in gassy mines. Other types of locomotives that are, or have been; used are steam locomotives, compressed air locomotives, and petrol locomotives; curiously enough, the so-called fireless locomotive using superheated water, which is quite popular in German collieries, appears never to have been even considered, although it no doubt presents certain advantages in fiery mines.

The third chapter of the bulletin deals with the lay-out of the shaft bottom; this section is of com-

NO. 2777 , VOL. I I I] 